\title{
An annual nitrogen budget for a seagrass Zostera marina population
}

\author{
Morten Foldager Pedersen, Jens Borum
}

Freshwater-Biological Laboratory, University of Copenhagen, Helsingørsgade 51, DK-3400 Hillerød, Denmark

\begin{abstract}
The nitrogen dynamics of an eelgrass Zostera marina L. population were assessed during an annual cycle by using measurements of seasonal changes in eelgrass biomass, production, losses and nitrogen content of different plant tissues. Estimated nitrogen uptake and reclamation (internal recycling) were compared to incorporation and theoretical requirements to assess the role of different nitrogen sources and recycling and to determine periods of potential nitrogen limitation. Maximum eelgrass biomass was $700 \mathrm{~g}$ dry wt $\mathrm{m}^{-2}$, annual production was $2388 \mathrm{~g}$ dry $\mathrm{wt}^{-2}$, and total nitrogen incorporation was $34.5 \mathrm{~g} \mathrm{~N} \mathrm{~m}^{-2} \mathrm{yr}^{-1}$. Estimated nitrogen requirements exceeded actual incorporation from June to September. Although eelgrass growth was moderately stimulated by fertilization of the sediment, the eelgrass population did not appear to be seriously nitrogen limited. Nitrogen uptake from the external media ( $49 \%$ from water column and $51 \%$ from sediment) supplied $73 \%$ of annual incorporation while internally reclaimed nitrogen accounted for $27 \%$. Reclamation provided the main contribution to incorporation into newly formed tissue in May and June, supporting high growth rates when external nitrogen availability was low. Externally recycled nitrogen in the sediment could potentially increase total recycling to about $50 \%$ of plant nitrogen incorporation.
\end{abstract}

\section{INTRODUCTION}

Eelgrass Zostera marina L. is the dominant seagrass in north-temperate coastal areas, with maximum biomasses of 200 to $700 \mathrm{~g} \mathrm{dry} \mathrm{wt} \mathrm{m}^{-2}$ and production rates reaching 1000 to $2000 \mathrm{~g}$ dry wt $\mathrm{m}^{-2} \mathrm{yr}^{-1}$ (Jacobs 1979, Zieman \& Wetzel 1980, Aioi et al. 1981, WiumAndersen \& Borum 1984, Roman \& Able 1988). Maintenance of high productivity requires high nutrient incorporation and eelgrass populations have been reported to suffer from nutrient limitation during summer (Orth 1977, Harlin \& Thorne-Miller 1981, Dennison et al. 1987, Short 1987, Murray et al. 1992). Yet, most of the eelgrass production occurs during summer, when nutrients are scarce and other autotrophs (phytoplankton and ephemeral algae) may suffer from severe nutrient limitation (Harlin \& Thorne-Miller 1981, SandJensen \& Borum 1991).

Eelgrass takes up nitrogen from both the water column and the sediment porewater (Iizumi \& Hattori 1982, Thursby \& Harlin 1982, Short \& McRoy 1984), and both nutrient sources seem to contribute substantially to total uptake under most in situ nitrogen condi- tions (Zimmerman et al. 1987, Hemminga et al. 1991). Despite the large sedimentary nitrogen pool, eelgrass nitrogen content declines during spring and summer (Harrison \& Mann 1975, Thayer et al. 1977, Pellikaan \& Nienhuis 1988), demonstrating that uptake is unable to meet the nitrogen demands during rapid eelgrass growth.

The nutrient content of seagrass tissues declines with increasing tissue age (Patriquin 1972, Harrison \& Mann 1975, Thayer et al. 1977. Walker 1989) inferring that nutrients are either leached to the external media or reclaimed from old tissues before these are lost. Reclamation of nutrients is a well-known mechanism of nutrient conservation among terrestrial plants (e.g. Chapin 1980), where reclaimed nutrients contribute to the incorporation in young, growing tissues, thereby reducing the demand for external supplies. Two independent experiments based on ${ }^{15} \mathrm{~N}$-techniques have shown that nitrogen reclamation also occurs in eelgrass and that more than $90 \%$ of the nitrogen lost from old eelgrass tissues was recovered in young leaves or rootsrhizomes, while only 5 to $10 \%$ of the reclaimed nitrogen could have been lost to the external media (Borum et al. 
1989, Pedersen \& Borum 1992). Assuming that the low figures of nitrogen loss through leaching can be extrapolated over the total annual cycle, the importance of internal nitrogen recycling for annual nitrogen incorporation can be estimated from seasonal changes in the nitrogen contents of eelgrass tissues of different age.

The need for import of 'new' nitrogen to the eelgrass bed may be further reduced by external regeneration of nutrients from decaying eelgrass tissues within the meadow. Dead roots and rhizomes, together with part of the shed leaves, decompose within the sediments of the eelgrass bed in close contact with active roots (Kenworthy \& Thayer 1984, Harrison 1989), thereby giving rise to uptake of 'regenerated' nitrogen. The annual production of well-developed eelgrass meadows may thus be based upon a great deal of internally and externally recycled nitrogen. However, 'new' nitrogen taken up as inorganic nitrogen from the water column or imported as settled seston-bound nitrogen, is needed to balance losses of nitrogen due to export of plant tissues from the meadow (Josselyn et al. 1983, Bach et al. 1986), denitrification in the rhizosphere (Koike \& Hattori 1978, Iizumi et al. 1980, Caffrey \& Kemp 1990), or to increase meadow size and density.

In the present paper we report eelgrass biomass, annual production, biomass losses, and seasonal changes of nitrogen content in different tissues. From these measurements we estimate nitrogen requirements, incorporation, losses, uptake, and reclamation for the eelgrass population. The aims were to examine the significance of different external and internal nitrogen sources relative to the annual nitrogen incorporation, and to determine temporal changes in the balance between nitrogen requirements and incorporation and thereby periods of potential nitrogen limitation.

\section{MATERIALS AND METHODS}

Study site and environment. The study was conducted from April 1988 to July 1989 in a homogeneous eelgrass bed located in Øresund approximately $10 \mathrm{~km}$ north of Copenhagen (the same site used by WiumAndersen \& Borum 1984). Mean water depth in the area was $1 \mathrm{~m}(0.7$ to $1.3 \mathrm{~m})$. The sediment of the seagrass bed consisted of coarse-grained sand and gravel.

Concentrations of inorganic nitrogen in the water and the sediment porewater were measured 14 times during the study period. Five sediment cores (diameter $5 \mathrm{~cm}$ ) were taken to $10 \mathrm{~cm}$ depth, placed in closed plastic bags and kept frozen until analysis. The porewater was separated from the sediment by direct filtration through a Whatman GF/C filter (under vacuum) and subsequently analysed for ammonium by the hypochlorite method (Solorzano 1969). Nitrate was not measured in the porewater because levels are reported to be insignificant in anoxic sediments (Boon 1986). Triplicate water samples were taken within the seagrass bed and were filtered (Whatman GF/C) and analysed for ammonium (Solorzano 1969) and nitrate (Strickland \& Parsons 1968).

Eelgrass biomass and production. Biomass and shoot density were measured 11 times during the study period by harvesting all living plant material in 4 randomly chosen circular plots $\left(0.125 \mathrm{~m}^{2}\right)$. Plants were cleaned, counted and separated into leaves and roots-rhizomes, and subsequently dried to constant weight at $90^{\circ} \mathrm{C}$. Growth measurements were performed by the in situ leaf marking method (Sand-Jensen 1975). An eelgrass turf $(40 \times 60 \mathrm{~cm})$ including sediment was removed from the bed and placed in a plastic box. The leaves of at least 30 shoots were marked with a waterproof felt pen (Penol 700) just above the leaf sheet of Leaves 4 to 6 (Fig. 1). The box with sediment and plants was returned to the eelgrass bed and left for the period needed for one new leaf to be produced (subsequently discussed as a plastochrone interval, P.I.) and then harvested. A plastochrone interval is approximately 8 to $25 \mathrm{~d}$. Leaf growth was measured as the displacement of marks on young leaves relative to the marks on the older (Leaves 4 to 6), non-growing leaves (which were used as reference points) plus the total length of newly formed leaves.

Nutrient limitation of leaf growth rate was assessed from fertilization experiments by adding nutrients to single (unreplicated) plots from July 1988 to July 1989. Approximately $25 \mathrm{~g}$ of fertilizer pellets ( $\mathrm{N}: \mathrm{P}: \mathrm{K}$; $16: 1.7: 4.1 \%$ ) were added into the sediment of experi-

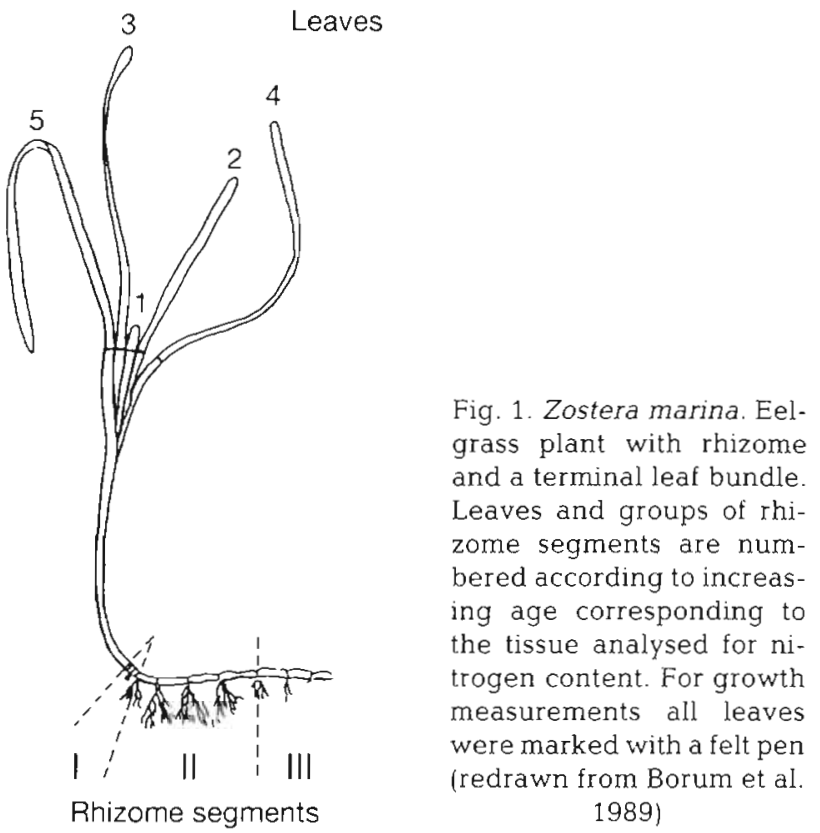


mental areas $\left(0.24 \mathrm{~m}^{2}\right)$. The resulting leaf growth rates of 20 to 30 marked plants were compared to leaf growth rates from unenriched (control) areas as stated above. Due to lack of proper replication data points were tested as pairs of individual means using Wilcoxon ranked sign test.

Leaf production was calculated as the product of average leaf growth rate ( $\mathrm{cm} \mathrm{shoot}^{-1} \mathrm{~d}^{-1}$ ), shoot density $\left(\mathrm{m}^{-2}\right)$, and specific weight of Leaf 4 ( $\mathrm{g}$ dry wt $\left.\mathrm{cm}^{-1}\right)$. Rootrhizome growth was estimated from the P.I. (because 1 internode is produced per leaf produced). Root-rhizome production was calculated as the product of average internode production $\left(\mathrm{d}^{-1}\right)$, weight of fully grown internodes and associated roots ( $g$ dry wt internode $\mathrm{e}^{-1}$ ) and shoot density $\left(\mathrm{m}^{-2}\right)$. Monthly and annual production were calculated by linear interpolation.

Monthly loss of above- and below-ground biomass was calculated as

$$
\text { Loss }=B_{t}-B_{0}-\text { Production }
$$

where $B_{1}$ and $B_{0}$ are the biomass ( $g$ dry wt $\mathrm{m}^{-2}$ ) at the beginning and at the end of a month respectively. Production and losses are in $\mathrm{g}$ dry $\mathrm{wt} \mathrm{m}^{-2} \mathrm{month}^{-1}$. Lass of above-ground biomass occurs due to leaf shedding and disappearance of whole leaf bundles. The number of leaves lost per plant per month was calculated as

$$
\text { Leaves }_{\text {lost }}=\text { Leaves }_{1}-\text { Leaves }_{0}-\text { Leaves }_{\text {produced }}
$$

To calculate above-ground biomass loss due to leaf shedding, the number of leaves lost was multiplied by the specific weight of the oldest leaf ( $g$ dry wt leaf ${ }^{-1}$ ) and shoot density $\left(\mathrm{m}^{-2}\right)$. Monthly loss of whole leaf bundles was calculated as the difference between total loss and loss due to leaf shedding.

Plant dimensions and nitrogen content. Eelgrass plants were collected 12 times during the study period for measurements of dimensions and $N$ content. On each sampling date 9 plants (Fig. 1) were cleaned and separated into individual plant parts (i.e. Leaves 1 to 6 of increasing age; and rhizome groups I to III, I: the 3 youngest internodes with undeveloped roots, II: the next 4 internodes with well-developed roots and III: the 3 oldest internodes with senescent roots). Agespecific leaf length, area and dry weight $\left(90^{\circ} \mathrm{C}\right.$ to constant weight) were recorded for the leaves, and age-specific dry weight was measured for each rootrhizome group. Nitrogen content was determined on dried, ground samples of the different plant tissues using a Perkin Elmer CHN elemental analyzer. Total plant-bound nitrogen was calculated as the product of eelgrass biomass ( $g$ dry wt $\mathrm{m}^{-2}$ ) and average nitrogen content (mg $\mathrm{N} \mathrm{g}^{-1}$ dry wt).

Nitrogen dynamics. Requirements, actual incorporation, uptake and reclamation of nitrogen for the eelgrass population were computed and integrated on a square meter basis from eelgrass biomass, production, losses and nitrogen contents of the different tissues. Nitrogen requirements were calculated as eelgrass production, using growth rates of fertilized plants, multiplied by critical nitrogen levels (sensu Gerloff \& Krombholz 1966) of leaves and roots-rhizomes. Critical nitrogen levels, above which eelgrass growth should not be limited by nitrogen availability, were $1.8 \%$ of dry wt for leaf bundles (Short 1987, Duarte 1990) and $1.0 \%$ of dry wt for roots-rhizomes. The critical level for roots-rhizomes was arbitrarily chosen as the observed nitrogen content of below-ground plant parts at the time when average nitrogen content of leaves was $1.8 \%$ of dry weight. Nitrogen incorporation associated with growth was calculated as production multiplied by the nitrogen concentration of fully grown plant parts (Leaf 3 and root-rhizome group II). Nitrogen losses were calculated as monthly biomass losses multiplied by average nitrogen concentrations of the oldest leaf (Leaf 6) or oldest root-rhizome group (rootrhizome III), respectively. Loss of nitrogen related to loss of leaf bundles (e.g. flowering shoots) was estimated by using average nitrogen content of whole leaf bundles. Uptake of nitrogen was calculated as monthly net increase in nitrogen biomass plus nitrogen losses, and nitrogen reclamation was determined as the difference between incorporation and uptake.

Nitrogen uptake via roots and leaves could not be separated by the computations described above. Root versus leaf uptake was estimated using the kinetic constants $\left(V_{\max }\right.$ and $K_{\mathrm{m}}$ ) reported by Iizumi \& Hattori (1982), the data for leaf and root-rhizome biomass, and the concentrations of dissolved inorganic nitrogen in water and sediment porewater. The uptake kinetics represent summer uptake only and likely overestimate absolute values of uptake outside this period due to the inverse relationship between uptake rates and nitrogen content within plant tissues (e.g. D'Elia \& DeBoer 1978). Uptake may also be suppressed by low light and low temperature (Lobban et al. 1985). However, we assumed that the relative contribution of leaf and root uptake was unaffected by season and thus used the ratio calculated from uptake kinetics to describe the relative importance of leaf versus root uptake.

Error estimation. Since the figures of nitrogen dynamics were calculated as combinations of many individual parameters, each measured with error, we used a bootstrap procedure (Efron \& Tibshirani 1986) to estimate means and standard errors for the combined results. The individual variables were assumed to be normally distributed with observed means and standard deviations (n varied between 3 and 25), and standard errors of the combined results were computed using Monte Carlo resampling $(n=100)$ of the different individual variables combined. 


\section{RESULTS}

\section{Inorganic nitrogen in water column and sediment}

Concentrations of $\mathrm{NO}_{3}^{-}+\mathrm{NO}_{2}{ }^{-}$in the water column were up to $6 \mu \mathrm{M}$ in winter and spring but below $1.5 \mu \mathrm{M}$ from May to September (Fig. 2A). Water column $\mathrm{NH}_{4}{ }^{+}$ranged between 1 and $5 \mu \mathrm{M}$ with lowest concentrations during early summer. Sediment porewater $\mathrm{NH}_{4}{ }^{+}$were always at least 1 order of magnitude higher (240 to $1300 \mu \mathrm{M}$ ) than water column concentrations (Fig. 2B). Porewater concentrations were highest in winter and relatively low (240 to $300 \mu \mathrm{M}$ ) throughout summer and fall.

\section{Eelgrass biomass development and production}

Maximum eelgrass biomass (710 $\mathrm{g}$ dry wt $\mathrm{m}^{-2}$ ) was reached in August 1988 and minimum biomass

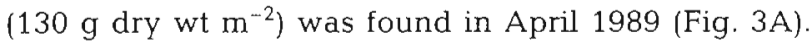
Leaf biomass exceeded root biomass during summer (root: shoot ratio $=0.55$ ) and vice versa in late winter and early spring. Shoot density ranged from 1320 to 2080 shoots $\mathrm{m}^{-2}$, and the number of leaves per shoot varied from 4.7 in late summer to 6.9 in spring (data not shown). Daily leaf growth rates reached a maximum in

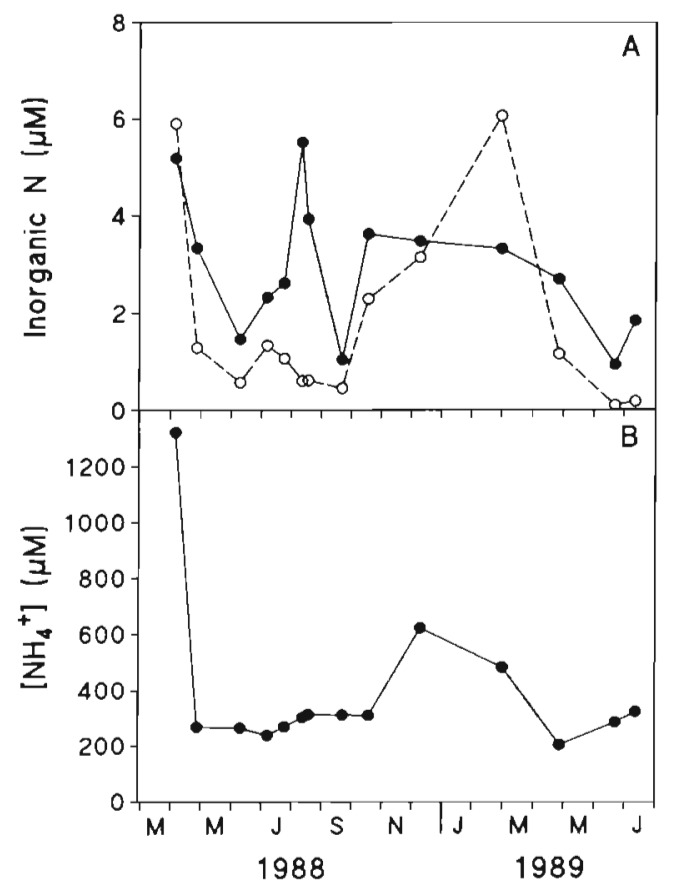

Fig. 2. Zostera marina. Seasonal variation in external nitrogen concentrations. (A) Concentrations of (-) $\mathrm{NH}_{4}{ }^{+}$and (O) $\mathrm{NO}_{3}^{-}$ in the water column of the eelgrass meadow. (B) $\mathrm{NH}_{4}{ }^{+}$ concentration in the sediment porewater of the meadow

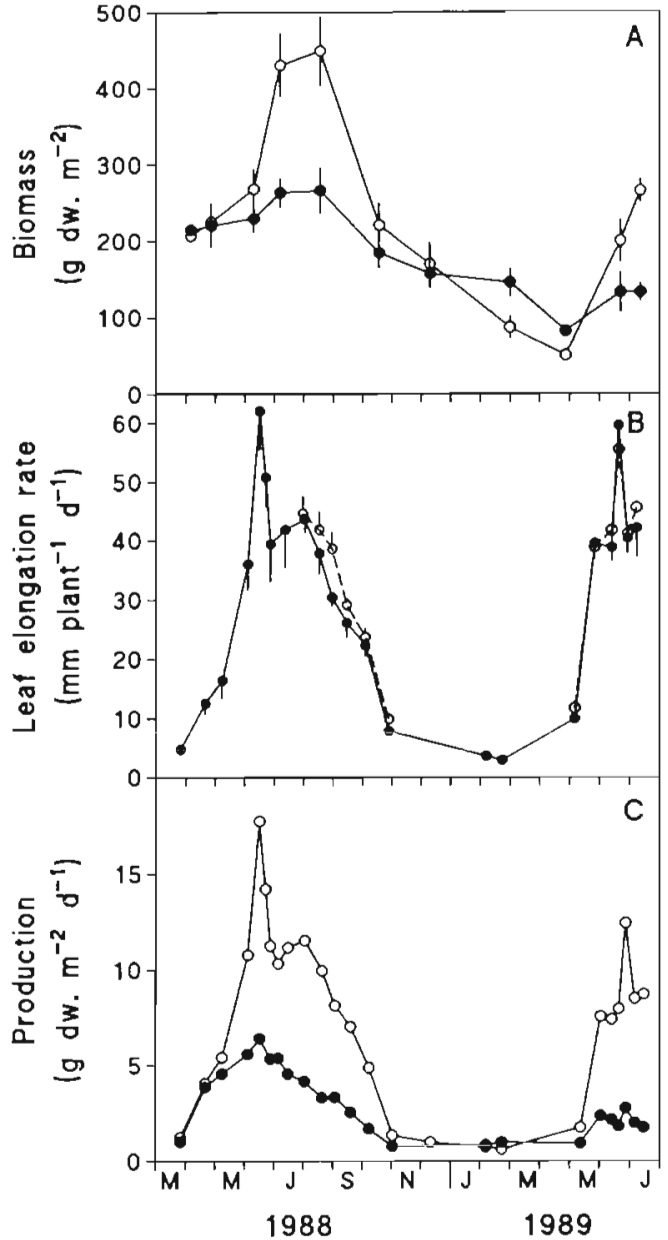

Fig. 3. Zostera marina. (A) Seasonal development in (0) above-ground and (*) below-ground eelgrass biomass (avg. $\pm 1 \mathrm{SE}, \mathrm{n}=4$ ). (B) Seasonal variation in leaf elongation rate among (•) unfertilized and $(0)$ fertilized eelgrass plants (avg. $\pm 95 \%$ confidence internal). (C) Seasonal variation of productivity in eelgrass, (O) above-ground and (•) below-ground

June (59.5 mm shoot ${ }^{-1}$ ) and a minimum in winter (3.6 $\mathrm{mm} \mathrm{shoot}^{-1}$, Fig. 3B), and the P.I. ranged from $8.7 \mathrm{~d}$ in early June to more than $50 \mathrm{~d}$ in winter. Nutrient addition resulted in a moderate $(-7$ to $+27 \%)$, though overall significant (Wilcoxon, $p<0.05$ ), increase of leaf growth rates relative to controls (Fig. 3B).

Total eelgrass production ranged from $1.5 \mathrm{~g}$ dry $\mathrm{wt}$ $\mathrm{m}^{-2} \mathrm{~d}^{-1}$ during winter to $24 \mathrm{~g}$ dry wt $\mathrm{m}^{-2} \mathrm{~d}^{-1}$ in June (Fig. 3C) resulting in monthly production rates from $49 \mathrm{~g}$ dry wt $\mathrm{m}^{-2}$ in February to $586 \mathrm{~g}$ dry wt $\mathrm{m}^{-2}$ in June. Annual production (July 1988 to June 1989) was $2388 \mathrm{~g}$ dry wt $\mathrm{m}^{-2}$ corresponding to $907 \mathrm{~g} \mathrm{C} \mathrm{m}^{-2}$ with $66 \%$ above-ground and $34 \%$ below-ground. Annual eelgrass losses due to leaf shedding, loss of whole leaf bundles (including flowering shoots), and senescence of old roots-rhizomes represented $2657 \mathrm{~g}$ dry wt $\mathrm{m}^{-2}$ and thus exceeded annual production. Losses followed 
the seasonal pattern of production with a time lag of ca $2 \mathrm{mo}$, which is similar to the average life span of eelgrass leaves.

\section{Nitrogen tissue concentrations}

Average nitrogen concentrations in leaves were highest in April (about $3 \%$ of dry weight), but declined rapidly during May and June to a minimum of about $0.9 \%$ in early July (Fig. 4A). From July concentrations increased to attain maximum levels again in winter. The average concentration in whole leaf bundles was below $1.8 \%$ of dry weight from early June to mid-October. Nitrogen concentrations in roots-rhizomes showed a

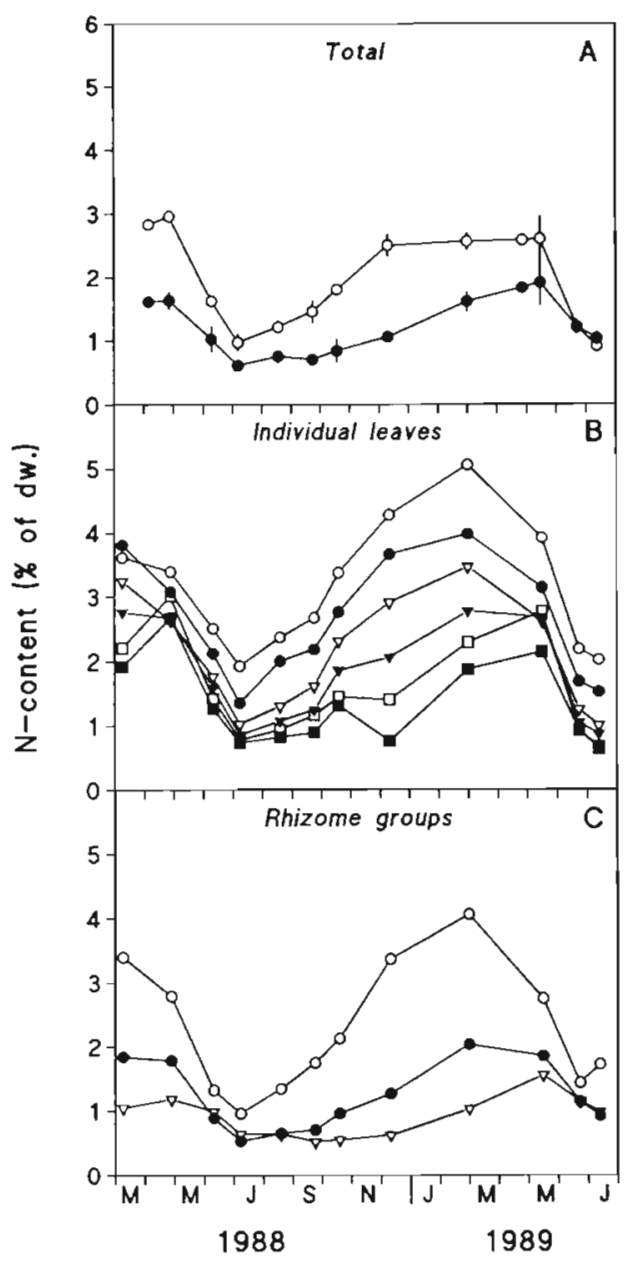

Fig. 4. Zostera marina. Seasonal variation of tissue nitrogen concentrations in eelgrass. (A) Average concentrations of (O) above-ground and ( $)$ below-ground tissues (avg. $\pm 1 \mathrm{SE}$, $\mathrm{n}=3$ ). (B) Tissue concentrations of individual leaves of increasing age: $(0)$ Leaf $1 ;(\bullet)$ Leaf $2 ;(\nabla)$ Leaf $3 ;(\nabla)$ Leaf $4 ;(\square)$ Leaf 5; and ( Leaf 6 . (C) Tissue concentrations of individual rhizome groups of increasing age: (0) Group I, (•) Group II and $(\nabla)$ Group III

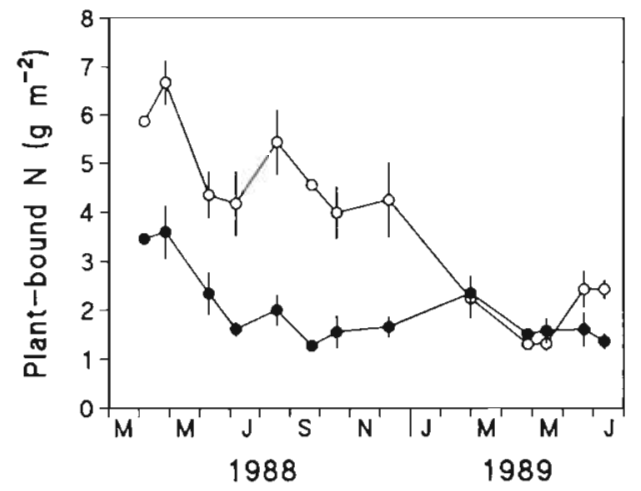

Fig. 5. Zostera marina. Seasonal variation in (0) aboveground and $(\bullet)$ below-ground plant-bound nitrogen (avg $\pm 1 \mathrm{SE}, \mathrm{n}=3$ )

similar seasonal pattern as in leaves although at a lower level ( 0.6 to $1.6 \%$ of dry weight). Nitrogen concentrations of individual leaves changed with season and declined with increasing age (ANOVA, p<0.01) (Fig. 4B). In April, however, all leaves had approximately the same concentration, simultaneous with the highest average concentration of nitrogen in the aboveground biomass. Fast growth in spring enhanced differences among leaves, which were maintained until next spring. Nitrogen concentrations in the different rootrhizome groups (Fig, 4C) also declined with age $(p<0.01)$, and the age patterns followed the same seasonal variations as those of leaf concentrations. The total amount of plant-bound nitrogen (Fig. 5) varied from 4 to $10 \mathrm{~g} \mathrm{~N} \mathrm{~m}^{-2}$, with highest amounts in the aboveground biomass. Seasonal variation was buffered by the inverse relationship between eelgrass biomass and nitrogen content. Total plant-bound nitrogen declined throughout the study period due to the net reduction in eelgrass biomass (Fig. 3A).

\section{Nitrogen dynamics}

Total nitrogen incorporation into eelgrass biomass ranged from $35 \mathrm{mg} \mathrm{N} \mathrm{m}^{-2} \mathrm{~d}^{-1}$ in winter to $257 \mathrm{mg} \mathrm{N} \mathrm{m}^{-2}$ $\mathrm{d}^{-1}$ in June 1988 (Fig. 6), and the annual incorporation (July 1988 to June 1989) was $34.5 \mathrm{~g} \mathrm{~N} \mathrm{~m}^{-2}$. The nitrogen requirements exceeded incorporation from June to September 1988 and again in June 1989, whereas incorporation exceeded requirements during the rest of the year. Nitrogen uptake was high from April to October 1988 and, although at a lower level, again in spring 1989. Nitrogen uptake varied between 28 and $165 \mathrm{mg} \mathrm{N}$ $\mathrm{m}^{-2} \mathrm{~d}^{-1}$ and covered plant requirements from October to April. On an annual basis nitrogen uptake accounted for $73 \%$ of total nitrogen incorporated into growing tissues. Reclamation of nitrogen from old tissues accounted for 


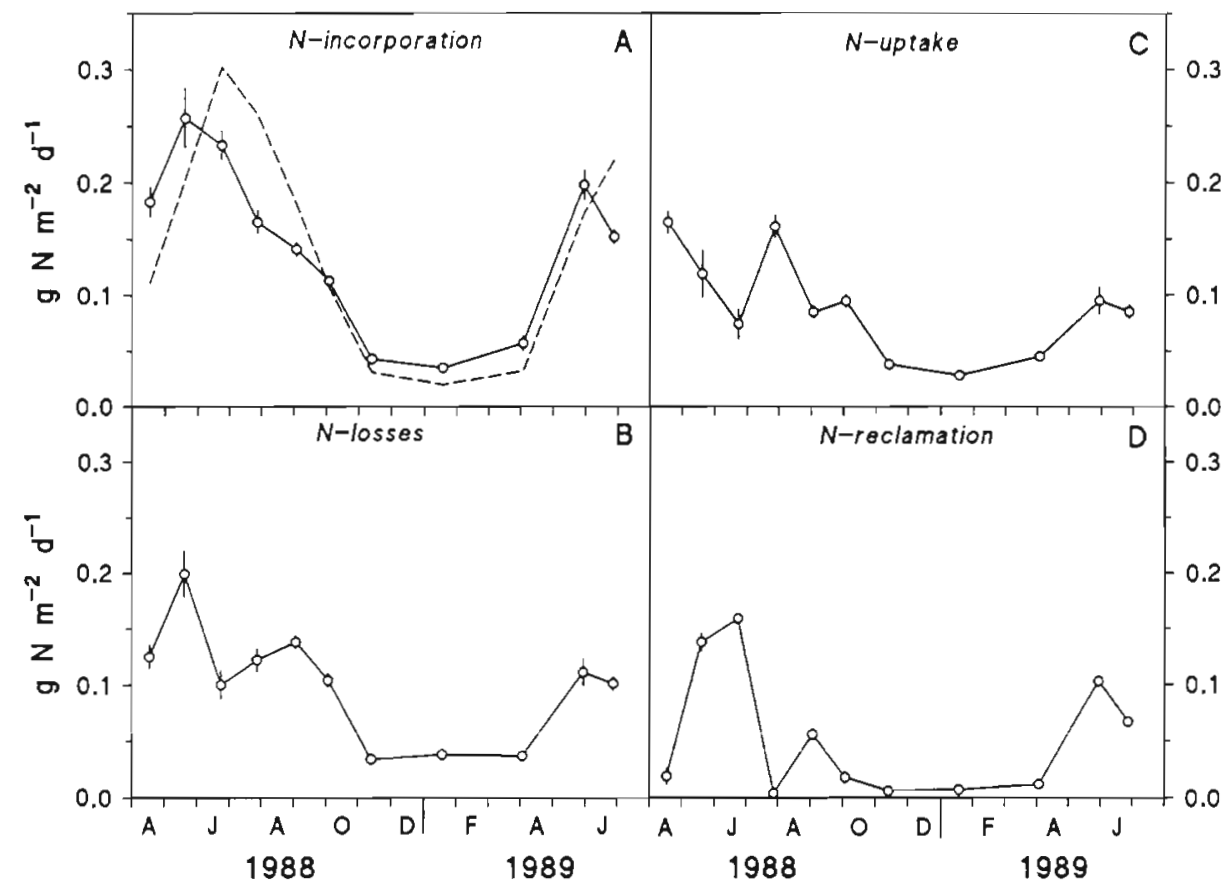

Fig. 6. Zostera marina. Seasonal pattern of areal eelgrass nitrogen dynamics. (A) $\mathrm{N}$ incorporation into new tissues and estimated $\mathrm{N}$ requirements (dashed line). (B) N iosses due to loss of eelgrass tissues. (C) N uptake from the external medium. (D) $\mathrm{N}$ reclamation. All values are avg. \pm 1 SE $(n=100)$ the remaining $27 \%$ and ranged between 0 and $68 \%$ of the nitrogen incorporation into new tissues with highest relative contribution in May and June (1988: 54 to $68 \%$; 1989: 49 to $53 \%$ ). Losses of tissue-bound nitrogen followed about the same seasonal pattern as incorporation and were on an annual basis $27.1 \mathrm{~g} \mathrm{~N} \mathrm{~m}^{-2}$. A significant fraction of this nitrogen $(29.0 \%)$ was lost directly to the sediments as dead roots and rhizomes and the rest was lost as leaves or leaf bundles.

By using the kinetic parameters described by Iizumi \& Hattori (1982), we estimated that total annual nitrogen uptake was $50 \mathrm{~g} \mathrm{~N} \mathrm{~m}^{-2}$ and that uptake by roots covered between 38 and $64 \%$ of total uptake. Roots (50.6\%) and leaves (49.4\%) contributed equally to total annual uptake. Annual nitrogen uptake was $25.3 \mathrm{~g} \mathrm{~N} \mathrm{~m}^{-2}$ when calculated from the eelgrass growth and population dynamics. Losses exceeded uptake due to the net decline in total plant-bound nitrogen during the study period.

\section{DISCUSSION}

Annual rates and patterns of biomass, production and losses resemble those in comparable data published on Zostera marina (Sand-Jensen 1975, Jacobs 1979, Wium-Andersen \& Borum 1984, Roman \& Able 1988), although maximum biomass and annual production are in the upper range of reported values. Annual production rates exceeding $2000 \mathrm{~g}$ dry wt $\mathrm{m}^{-2}$ are among the highest reported for coastal ecosystems. Although eelgrass tissues are relatively low in nitrogen compared to levels found in fast-growing phytoplankters (Duarte 1992), the associated nitrogen incorporation of $34.5 \mathrm{~g} \mathrm{~N} \mathrm{~m}^{-2} \mathrm{yr}^{-1}$ is high and at about the same level as annual nitrogen incorporation of phytoplankton in productive coastal waters.

Nutrient availability is often low during summer in coastal waters due to substantial uptake by autotrophic organisms, and nutrient limitation of seagrass growth and biomass development has been documented in several studies, e.g. Zostera marina (Orth 1977, Harlin \& Thorne-Miller 1981, Short 1987, Murray et al. 1992), Heterozostera tasmanica (Bulthuis \& Woelkering 1981, Bulthuis et al. 1992), Syringodium filiforme (Short et al. 1985, Powell et al. 1989, Short et al. 1990) and Cymodocea nodosa (Perez et al. 1991). The nitrogen content of plant tissues has been used as an indicator of the nutritional status of submerged macrophytes (Gerloff \& Krombholz 1966), and according to Short (1987) and Duarte (1990) seagrass growth is nitrogen limited when average nitrogen concentrations in the leaves decrease below $1.8 \%$ of dry weight In the present study average nitrogen concentrations were below that limit from June to mid-October, consistent with the imbalance between requirements and uptake in this period (Fig. 6). However, according to the fertilization experiments, eelgrass growth seemed only moderately limited by low nutrient availability, and effects of fertilization were not exclusively confined to the period of low nitrogen content. From the lack of major responses to fertilization and from the observation of sustained high leaf growth rates 
throughout summer we infer that variables other than nutrients, such as light, must have been the main controlling factor for eelgrass growth (Sand-Jensen \& Borum 1983, Dennison 1987).

The large annual nitrogen incorporation into new tissues was supported by uptake from the external media and by internal recycling, but the relative importance of these sources varied with season as a function of changes in external and internal nitrogen availability. Nitrogen uptake covered the major part of annual incorporation, and, estimated from kinetic parameters (Iizumi \& Hattori 1982), both water phase and sediment appeared to be important sources of nitrogen. We calculated root uptake to be most important in May and June, when inorganic nitrogen in the water column was depleted and leaf biomass relative to root-rhizome biomass was still low. With increasing availability of nitrogen in the water and increasing leaf biomass later during the summer our calculations indicate that leaf uptake should exceed root uptake.

On an annual basis roots and leaves should contribute about equally to total uptake. Similar conclusions, also using calculations based on nitrogen uptake kinetics, were reached by Zimmerman et al. (1987) and Hemminga et al. (1991) but they conflict with the general assumption that the sediment comprises the main source of nutrients for rooted macrophytes (e.g. Carignan \& Kalff 1980, Barko \& Smart 1981). However, calculations of nutrient uptake based on uptake kinetics may, like in our study, overestimate actual uptake when extrapolated to a total annual cycle. The discrepancy between kinetic-and mass-balance-based uptake rates were small during summer but large during the period of high nutrient availability and low growth in winter, leaving room for substantial error. The question of eelgrass root versus leaf uptake, therefore, needs direct experimental documentation to be answered.

Nitrogen is reclaimed from old eelgrass tissues before these are lost, and thereby the demand for external nitrogen is reduced (Borum et al. 1989 , Pedersen \& Borum 1992). We found that nitrogen reclamation accounted for $12 \%$ of the nitrogen incorporation into newly formed tissues during the late summer period of 1988 (Pedersen \& Borum 1992). In a review on nitrogen dynamics in eelgrass Hemminga et al. (1991) proposed a 25\% reduction of annual nitrogen requirements due to internal recycling, which corresponds well to the $27 \%$ of annual nitrogen incorporation estimated in the present study. Though nitrogen reclamation covered less than one third of total annual nitrogen incorporation into new tissues, this conservation mechanism accounted for more than $50 \%$ of the incorporation during the critical period of maximum eelgrass growth in May and June. The importance of nitrogen reclamation for total annual incorporation depends on winter survival of the eelgrass population. If the spring biomass of eelgrass is low (due to heavy winter storms or ice scouring), like in spring 1989, the relative contribution from reclamation to annual nitrogen incorporation is low, but if spring biomass is high, like in spring 1988, reclamation contributes more. However, independent of surviving biomass, internal nitrogen recycling is important by sustaining high eelgrass growth during early summer, when external nitrogen availability is low.

Reclamation of nutrients is a well-known phenomenon in perennial, terrestrial plants (Chapin 1980 Jonasson 1989, Chapin \& Moilanen 1991), and was recently documented for eelgrass (Borum et al. 1989, Pedersen \& Borum 1992). Internal recycling of nutrients has been shown to be positively related to nutrient pool-size within terrestrial plants (e.g. Chapin \& Kedrowski 1983), and the same seemed to be the case for eelgrass. During winter and spring, uncoupled nutrient uptake and plant growth allowed nitrogen accumulation within eelgrass, as has been reported for perennial macroalgae (Chapman \& Craigie 1977. Zimmerman \& Kremer 1986). Therefore a large internal pool of nitrogen was open to reclamation at the beginning of the active growth season, and nitrogen could be internally recycled during May and June. Reclamation decreased dramatically in July and onwards, when nitrogen concentrations in the older leaves dropped to below $1.0 \%$ of dry weight. This suggests that there is a minimum or residual nitrogen content located in structural cell components which cannot be remobilized and reallocated, and that reclamation ceases when the nitrogen content of older leaves approaches this level.

Nutrients for eelgrass growth may also be externally recycled within the seagrass bed. Nitrogen incorporation can be separated into 'new' and 'regenerated' nitrogen, although the meaning of these terms in a seagrass context differs slightly from that of the oceanographic analogues (sensu Dugdale \& Goering 1967). 'New' nitrogen, here defined as nitrogen originating from all sources but eelgrass itself, is imported as dissolved inorganic nitrogen in the water-phase, as organic seston being trapped and mineralized within the meadow (Fonseca et al. 1982), and as $\mathrm{N}_{2}$ fixation in the seagrass rhizosphere (Capone 1982). 'Regenerated' nitrogen originates partly from internal recycling but also from eelgrass tissues decomposing inside the bed. Shed leaves are either trapped in or exported from the bed (Hemminga et al. 1991, and references therein), while dead roots and rhizomes almost always decompose within the sediments of the bed providing close contact between source (detrital matter) and sink (live eelgrass roots) 
Mineralized nitrogen may diffuse to the water column or be lost through enhanced denitrification activity in the macrophyte bed (Henriksen \& Kemp 1988, Caffrey \& Kemp 1990). However, reported rates of denitrication in eelgrass beds are moderate ( 1 to $2 \mathrm{~g}$ $\mathrm{N} \mathrm{m}^{-2} \mathrm{yr}^{-1}$; e.g. Iizumi et al. 1980, Kaspar 1983) and only seem to balance import through $\mathrm{N}_{2}$ fixation (up to $2.4 \mathrm{~g} \mathrm{~N} \mathrm{~m}^{-2} \mathrm{yr}^{-1}$; e.g. Capone 1982, Kenworthy et al. 1987). If we assume that all nitrogen from decomposing roots and rhizomes was recycled back to live eelgrass, external recycling could provide $7.8 \mathrm{~g} \mathrm{~N} \mathrm{~m}^{-2}$ $\mathrm{yr}^{-1}$, or $23 \%$ of total nitrogen incorporation. This figure may be higher due to decomposition of trapped leaves inside the meadow, or lower if the remineralized nutrients escape the sediment or are taken up by other organisms in competition with eelgrass. Accordingly, internal plus external recycling of nitrogen may potentially account for more than half of the nitrogen incorporated into eelgrass growth annually. However, this may not be the case for newly established eelgrass meadows increasing in meadow size, plant size, and plant density; initially such meadows may rely on 'new' nitrogen and only with further development of the meadow does externally 'regenerated' nitrogen become important.

Several subtropical and tropical seagrasses form dense beds and have a similar life-form and growth strategy as eelgrass. We suggest that future work on the nutrient dynamics of such seagrasses inhabiting more permanently nutrient-poor areas should focus on sources for nutrient uptake and assessment of both internal and external recycling to evaluate whether these species use the same strategies as eelgrass in obtaining sufficient nutrients to support high annual rates of production.

Acknowledgements. We gratefully acknowledge the cooperation and analytical support provided by Peter Kofoed, Danish Environmental Research Institute, Roskilde. We thank D. I. Walker, G. A. Kendrick, K. J. McGlathery and 3 referees for constructive comments on the manuscript and $C . M$. Duarte for valuable assistance with the bootstrapping procedure. This study was supported by the Danish Agency of Enviconmental Protection under the ' $N$, P and Organic matter Research Programme' and the 'Marine Research Programme in Denmark'. M.F.P. was supported by grant no. 89-0080 from the Carlsberg Foundation.

\section{LITERATURE CITED}

Aioi, K., Mukai, H., Koike, I., Ohtsu, M., Hattori, A. (1981). Growth and organic production of eelgrass (Zostera marina L.j in temperate waters of the Pacific coast of Japan. II. Growth analysis in winter. Aquat. Bot. 10: 175-182

Bach, S. D., Thayer, G. W., LaCroix, M. W. (1986) Export of detritus from eelgrass (Zostera marina) beds near Beaufort, North Carolina, U.S.A. Mar. Ecol. Prog. Ser. 28: 265-278

Barko, J W., Smart, R. M. (1981). Sediment-based nutrition of submerged macrophytes. Aquat. Bot. 10:339-352

Boon, P. I. (1986). Nitrogen pools in seagrass beds of Cymodocea serrulata and Zostera capricorni of Moreton Bay, Australia. Aquat. Bot. 25: 1-19

Borum, J., Murray, L., Kemp, W. M. (1989). Aspects of nitrogen acquisition and conservation in eelgrass plants. Aquat. Bot. 35: 289-300

Bulthuis, D. A., Axelrad, D. M., Mickelson, M. J. (1992). Growth of the seagrass Heterozostera tasmanica limited by nitrogen in Port Phillip Bay, Australia. Mar. Ecol. Prog. Ser. 89: 269-275

Bulthuis, D. A., Woelkering, W. J. (1981). Effects of in situ nitrogen and phosphorus on the seagrass Heterozostera tasmanica (Martens ex Aschers.) den Hartog in Western Port, Victoria, Australia. J. exp. mar. Biol. Ecol. 53: 193-207

Caffrey, J. M., Kemp, W. M. (1990). Nitrogen cycling in sediments with estuarine populations of Potamogeton perfoliatus and Zostera marina. Mar. Ecol. Prog. Ser. 66 . $147-160$

Capone, D. G. (1982). Nitrogen fixation (acetylene reductionj by rhizosphere sediments of the eelgrass, Zostera manina L. Mar. Ecol. Prog. Ser. 10:67-75

Carignan, R., Kalff, J. (1980). Phosphorus sources for aquatic weeds: water or sediments? Science 207: 987-988

Chapin, F. S. (1980). The mineral nutrition of wild plants. Ann. Rev. Ecol. Syst. 11: 233-260

Chapin, F. S., Kedrowski, R. A. (1983). Seasonal changes in nitrogen and phosphorus fractions and autumn retranslocation in evergreen and deciduous taiga trees. Ecology 64: $376-391$

Chapin, F. S., Moilanen, L. (1991). Nutritional controls over nitrogen and phosphorus resorption from Alaskan birch leaves. Ecology 72: 709-715

Chapman, A. R. O., Craigie, J. S. (1977). Seasonal growth in Laminaria longicruris: relations with dissolved inorganic nutrients of nitrogen. Mar. Biol. 40: 197-205

D'Elia, C. F. DeBoer, J. A. (1978). Nutritional studies of two red algae. II. Kinetics of ammonium and nitrate uptake. J. Phycol. 14: 266-272

Dennison. W. C. (1987). Effects of light on seagrass photosynthesis, growth and depth distribution. Aquat. Bot. 27: $15-26$

Dennison, W. C., Aller, R. C., Alberte, R. S. (1987). Sediment ammonium availability and eelgrass (Zostera marina) growth. Mar. Biol. 94: 469-477

Dugdale, R. C., Goering, J. J (1967). Uptake of new and regenerated forms of nitrogen in primary productivity Limnol. Oceanogr. 12: 196-206

Duarte, C. M. (1990). Seagrass nutrient content. Mar Ecol Prog. Ser. 67: 201-207

Duarte. C. M. (1992). Nutrient concentrations of aquatic plants patterns across species. Limnol. Oceanogr. 37: 882-889

Efron, B., Tibshirani, R. (1986). Bootstrap methods for standard errors, confidence intervals, and other measures of statistical accuracy. Statist. Sci. 1: 54-77

Fonseca, M. S., Fisher, J S., Zieman, J. C., Thayer, G. W (1982). Influence of the seagrass Zostera marina L. on current flow. Estuar. coast. Shelf Sci. 15: 351-364

Gerloff, G. C., Krombholz. P. H. (1966). Tissue analysis as a measure of nutrient availability for the growth of angiosperm aquatic plants. Limnol. Oceanogr. 11. 529-537

Harlin, M. M., Thorne-Miller, B. (1981). Nutrient enrichment of seagrass beds in a Rhode Island coastal lagoon. Mar. Biol. 65: 221-229

Harrison, P. G. (1989). Detntal processing in seagrass systems: a review of factors affecting decay rates, remineralization and detrivory. Aquat. Bot. 23: 263-288 
Harrison, P. G., Mann, K. H. (1975). Chemical changes during the seasonal cycle of growth and decay in eelgrass (Zostera marina) on the Atlantic coast of Canada. J. Fish. Res. Bd Can. 32: 615-621

Hemminga, M. A., Harrison, P. G., van Lent, F. (1991). The balance of nutrient losses and gains in seagrass meadows. Mar. Ecol. Prog. Ser 71:85-96

Henriksen, K., Kemp, W. M. (1988). Nitrification in estuarine and coastal marine sediments. In: Blackburn, $T H$. Sørensen, J. (eds.) Nitrogen cycling in coastal marine environments. John Wiley \& Sons, Chichester, p. 207-250

Iizumi, H., Hattori, A. (1982). Growth and organic production of eelgrass (Zostera marina L.) in temperate waters of the Pacific coast of Japan. III. The kinetics of nitrogen uptake. Aquat. Bot. 12: 245-256

lizumi, H., Hattori, A., McRoy, C. P. (1980). Nitrate and nitrite in interstitial waters of eelgrass beds in relation to the shizosphere. J. exp. mar. Biol. Ecol. 47: 191-201

Jacobs, R. P. W. M. (1979). Distribution and aspects of the production and biomass of eelgrass, Zostera marina L., at Roscoff, France. Aquat. Bot. 7: 151-172

Jonasson, S. (1989). Implications of leaf longevity, leaf nutrient reabsorption and translocation for the resource economy of five evergreen plant species. Oikos 56: $121-131$

Josselyn, M. N., Calliet, G. M., Niesen, T M., Cowen, R., Hurley, A. C., Connor, J., Hawes, S. (1983). Composition, export and faunal utilization of drift vegetation in the Salt River submarine canyon. Estuar. coast. Shelf Sci. 17 : $447-465$

Kaspar, H. F. (1983). Denitrification, nitrate reduction to ammonium, and inorganic nitrogen pools in intertidal sediments. Mar. Biol. 74: 133-139

Kenworthy, W. J., Currin, C., Smith, G., Thayer, G. (1987). The abundance, biomass and acetylene reduction activity of bacteria associated with decomposing rhizomes of two seagrasses, Zostera marina and Thalassia testudinum. Aquat. Bot. 27: 97-119

Kenworthy, W. J., Thayer, G. W. (1984). Production and decomposition of the roots and rhizomes of seagrasses, Zostera marina and Thalassia testudinum, in temperate and subtropical marine ecosystems. Bull. mar. Sci. 33: $364-379$

Koike, I., Hattori, A. (1978). Denitrification and ammonia formation in anaerobic sediments. Appl environ. Microbiol. 35: 853-857

Lobban, C. S., Harrison, P. J., Duncan, M. J. (1985). The physiological ecology of seaweeds. Cambridge University Press, Cambridge

Murray, L., Dennison, W. C., Kemp, W. M. (1992). Nitrogen versus phosphorus limitation for growth of an estuarine population of eelgrass (Zostera marina L.). Aquat. Bot. 44: $83-100$

Orth, R. J (1977). Effect of nutrient enrichment on growth of the eelgrass Zostera marina in the Chesapeake Bay, Virginia, USA. Mar. Biol. 44: 187-194

Patriquin, D. G. (1972). The origin of nitrogen and phosphorus for growth of the marine angiosperm Thalassia testudinum. Mar. Biol. 15: 35-46

Pedersen, M. F., Borum, J. (1992). Nitrogen dynamics of eelgrass Zostera marina during a late summer period of high growth and low nutrient availability. Mar. Ecol. Prog. Ser. 80: $65-73$

Pellikaan, G. C., Nienhuis, P. H. (1988). Nutrient uptake and release during growth and decomposition of eelgrass, Zostera manina L., and its effects on the nutrient dynamics of Lake Grevelingen. Aquat. Bot. 30: 189-214
Perez, M., Romero, J., Duarte, C. M., Sand-Jensen, K. (1991). Phosphorus limitation of Cymodocea nodosa growth. Mar Biol. 109: 129-133

Powell, G. V. N., Kenworthy, W. J., Fourqurean, J. W. (1989) Experimental evidence for nutrient limitation of seagrass growth in a tropical estuary with restricted circulation. Bull mar. Sci. 44: $324-340$

Roman, C. T., Able, K. W. (1988). Production ecology of eelgrass (Zostera marina L.) in a Cape Cod salt marshestuarine system, Massachusetts. Aquat. Bot. 32: 353-363

Sand-Jensen, K. (1975). Biomass, net production and growth dynamics in an eelgrass (Zostera marina L.) population in Vellerup Vig, Denmark. Ophelia 14: 185-201

Sand-Jensen, K., Borum, J. (1983). Regulation of growth of eelgrass (Zostera marina L.) in Danish coastal waters. Mar. Technol. Soc. J. 17(2): 15-21

Sand-Jensen, K., Borum, J. (1991). Ecology and interactions among phototrophic communities in temperate regions. Aquat. Bot. 41: 137-175

Short, F. T. (1987). Effects of sediment nutrients on seagrasses: literature review and mesocosm experiments. Aquat. Bot. 27: 41-67

Short, F. T., Davis, M. W., Gibson, R. A., Zimmermann, C. F. (1985). Evidence for phosphorus limitation in carbonate sediments of the seagrass Syringodium filiforme. Estuar coast. Shelf. Sci. 20: 419-430

Short, F. T., Dennison, W. C., Capone, D. G. (1990). Phosphorus limited growth of the tropical seagrass Syringodium filiforme in carbonate sediments. Mar. Ecol. Prog. Ser. 62: $169-174$

Short, F. T., McRoy, C. P. (1984). Nitrogen uptake by leaves and roots of the seagrass Zostera marina L. Bot. Mar. 27 $547-555$

Solorzano, L. (1969). Determination of ammonia in natural waters by the phenolhypochlorite method. Limnol. Oceanogr. 14: 799-801

Strickland, J. D. H., Parsons, T. R. (1968). A practical handbook of seawater analysis. Fish. Res. Bd Can. Bull. 167

Thayer, G. W., Engel, D. W., LaCroix, M. W. (1977). Seasonal distribution and changes in the nutritive quality of living. dead and detrital fractions of Zostera marina L. J. exp. mar. Biol. Ecol. 30: 109-127

Thursby, G. B., Harlin, M. M. (1982). Leaf-root interaction in the uptake of ammonia by Zostera marina. Mar Biol. 72 : 109-112

Walker, D. I. (1989). Regional studies - seagrass in Shark Bay, the foundations of an ecosystem. In: Larkum, A. W. D., McComb. A. J., Shepherd, S. A. (eds.) Biology of seagrasses. A treatise on the biology of seagrasses with special reference to the Australian region. Elsevier, Amsterdam, p. 182-210

Wium-Andersen, S., Borum, J. (1984). Biomass variation and autotrophic production of an epiphyte-macrophyte community in a coastal Danish area: I. Eelgrass (Zostera marina L.) biomass and net production. Ophelia 23:33-46

Zieman, C. J., Wetzel, R. G. (1980). Productivity in seagrasses: methods and rates. In: Phillips, R. C., McRoy, C. P. (eds.) A handbook of seagrass biology: an ecosystem perspective. Garland STPM, New York, p. 87-116

Zimmerman, R. C., Kremer, J. N. (1986). In situ growth and chemical composition of the giant kelp, Macrocystis pyrifera: response to temporal changes in ambient nutrient availability. Mar. Ecol. Prog. Ser. 27: 277-285

Zimmerman, R. C., Smith, R. D., Alberte, R. S. (1987). Is growth of eelgrass nitrogen limited? A numerical simulation of the effects of light and nitrogen on the growth dynamics of Zostera marina. Mar. Ecol. Prog. Ser. 41: 167-176 